Мирослав Павловић

Универзитет у Новом Саду

Филозофски факултет

Одсек за историју

mpavlovitch@yahoo.com
Оригинални научни рад

примљено: 27. јун 2011

прихваћено: 1. октобар 2011

\title{
ФОРСИРАНА ИЛИ АУТОНОМНА МОДЕРНИЗАЦИЈА? ОСМАНСКЕ РЕФОРМЕ У XVIII ВЕКУ У КОНТЕКСТУ ЕВРОПСКИХ УТИЦАЈА*
}

Сажетак: Рад разматра развој теорија модернизације и њихов утицај у савременој османистици, терминолошке непрецизности појмова модернизације и вестернизације (европеизације) са посебним освртом на савремене тезе о вишеструкој модерности. Посебно се посматра однос културног трансфера и интеракције, односно материјалног и духовног, да би се утврдила веза између утицаја модерних друштава на традиционална кроз модел наметнуте модернизације и аутономног развоја, иманентног историјском искуству самог друштва које се развија из предмодерног у модерно. Анализиране су перцепције о алтеритету и покушана идентификација симболичких знакова модерности, како то истиче Ентони Гиденс, односно оних обележја која нису карактеристична за традиционална друштва у циљу спецификовања карактера османске модерности.

Кључне речи: Османско царство, осамнаести век, модернизација, вишеструка модерност, вестернизација, реформе, децентрализација, централизација, културна интеракција, културни трансфер.

„East is East and West is West And never the twain shall meet" ${ }^{1}$

Rudyard Kipling

Теорије модернизације

Теоријско појмовно одређење у савременој османистици о XVIII веку условљено је непрецизношћу термина друштвене теорије којима се она служи. То није само случај у османистици, с обзиром да су теорије модернизације

\footnotetext{
* Рад је настао као фазни резултат републичког пројекта број 177002 под називом Војвођански простор $y$ контексту европске историје.

${ }^{1}$ Исток је Исток, Запад је Запад и то двоје се никад неће срести.
} 
заступљеније у каснијим историјским раздобљима. Захтев за теоријским у историографији најбоље је дефинисао Питер Берк констатацијом да без „прожимања историје и теорије нема изгледа за разумевање било прошлости било садашњости“, међутим, уколико не постоји конгруентност употребе термина, теорија је само форма. ${ }^{2}$ у савременој османистици појмови модернизација, европеизација и вестернизација користе се у различитом контексту, док је расправа усмерена на модалитете спољних утицаја и питање порекла реформи. С обзиром да је реч о оперативним средствима теорија модернизације и друштвеног развоја, потребно је најпре испитати њихова значења. Теорије модернизације дефинишу параметре и околности у којима ће традиционално друштво путем еволутивног развоја достићи модерност, при чему је парадигма модерности савремено „западно друштво“. 3 Занемарујући димензију прогресивног разумевања историје, највише пажње привукао је образац традиционално-модерно и као важан марксистички допринос теорија недовољне развијености. Постоји значајна сагласност о процесу индустријализације, језичке унификације, националној држави, као основним параметрима, или како би Ентони Гиденс рекао симболичким знацима модерности. ${ }^{4}$ Традиционална друштва почивају на елитистичком карактеру, високој насупрот масовне културе и аутаркичности, који не омогућавају никакав вид хомогенизације. Ентони Смит сматра да овакви чиниоци онемогућавају развој масовне идеологије попут национализма. ${ }^{5}$ Свест је заснована на принципима традиције, прошлост се доживљава као садашњост, а о секуларизму не може бити речи; док модерност одликује бирократизација, контролисана примена државне силе, као јединственог поретка у оквиру једне заједнице као и односа међу заједницама и коначно националним државама. Параметри модерности су свакако бројни, али је за

\footnotetext{
${ }^{2}$ Piter Berk, Istorija i društvena teorija, Beograd 2002, 27.

${ }^{3}$ Теорије модернизације развијане су непосредно после Другог светског рата, када је њихов основни задатак представљало испитивање којим ће се развојним путем кретати Трећи свет. Као одговор на Западну идеју о модернизацији настале су марксистичке теорије друштвеног развоја (недовољне развијености), које су указивале да је узрок неразвијености Трећег света капиталистичка експлоатација, због које вестернизација за њих неће представљати пут у модерност. Предраг Марковић, Теорија модернизачије и њена критичка примена на међуратну Југославију и друге источноевропске земље, Годишњак за друштвену историју, бр. 1, Београд 1994, 11-34; Исти, Концепт модернизације и/или вестернизације у новијој српској историји: одбацити или преиспитати?, Култура полиса, број 1, Нови Сад 2004, 39-58; Латинка Перовић, Између анархије и аутократије. Српско друштво на прелазима векова (XIX-XXI), Београд 2006, 50-55; Jovan Teokarević, Modernizacija i društveni razvoj, Beograd 1990.

${ }^{4}$ Када говори о симболичким знацима (tokens), Ентони Гиденс подразумева све појаве које утичу на креирање свести о припадности широј заједници. Зато је његова опсервација усмерена на простор-време, при чему издваја комуникацијске медије: новац, капиталистичко тржиште, поверење-ризик уместо фортуне, професионализација занимања... У основи ове анализе налази се свест о глобализацији, односно артикулација свести о припадности простору ширем од локалне заједнице са којом појединац има непосредно искуство. Глобализација тежи унификовању, односно кретању ка ,једном свету“ или „крају историје“. Теорије светских система, како објашњава Гиденс, пренаглашавају економску основу, разликујући центар, периферију и полупериферију. Entoni Gidens, Posledice modernosti, Beograd 1998, 1111.

${ }^{5}$ Antony D. Smith, Nationalism and Modernism. A Critical Survey of Recent Theories of Nations and Nationalism, London - New York 1998, 27-46.
} 
проучавање утицаја једних друштава на друга значајније питање како се врши модернизација, зашто су нека друштва модернија и који су утицаји једних на друге, модерних на предмодерна или традиционална. Постоје три основна критеријума, најчешће међусобно условљена, друштвено-политички, културни и економски. Уколико се избегне пренаглашавање једног од ових критеријума, кључни закључак како га је дефинисао Волт, Ростов поставља пред традиционална друштва захтев за променама у сфери економије, социјалне структуре и вредности. Симор Липсет сматра да је то могуће револуцијом или реформама, при чему су нужно праћени социјалним немирима, јер пут од традиционалног ка модерном доводи до привремене симбиозе укорењених и иновативних вредности и дифузионизма. Не треба занемарити да је степен привремености неизвестан, јер модернизација није загарантована простом чињеницом да пресликавање институција не успоставља и њихову аутоматску примену. Основна критика теорија модернизације се управо заснива на овим чињеницама, које оспоравају Талкота Парсонса у идеји о социјалној револуцији као неизбежној или Ајзенштата који пренаглашава улогу елите, односно бирократије. Барингтон Мур је зато истакао другачије путеве модерности, демократску и антидемократску модернизацију. Основни закључак је да нема јединствене теорије модернизације као што не постоји монолитан образац модерности. Теорије о неразвијеним друштвима, односно теорије друштвеног развоја, допуниле су идеје о модернизацији фокусирајући се на неразвијена подручја која су захваљујући Самиру Амину и Имануелу Волерстину названи периферијом, тврдећи да им теоретичари модернизације априори одређују пасивну улогу. ${ }^{6}$ Основно питање које се поставља јесте да ли може бити модернизације без Запада и да ли се модерним могу сматрати друштва која нису Западна или се нису модернизовала по истоименом обрасцу?

За разумевање одговора на ово питање потребно је објаснити концепт касне модернизације, односно признати да постоје вишеструке модерности. Касна модерност је појам који се односи на државе које нису биле под колонијалним утицајима Запада, попут Русије, Јапана и Турске. Њих карактерише аутономна модернизација као „властити пројекат“, што никако не кореспондира са вестернизацијом! ${ }^{7}$ Процес европеизације, за турског теоретичара Ибрахима Кају, подразумева евроцентричну слику, појам који одсликава европски идентитет и успоставља разлику између „цивилизованог Запада“ и „нецивилизованих других“. 8 Код концепта вишеструке модерности улога традиције није у конфронтацији са

\footnotetext{
${ }^{6}$ David Harrison, The Sociology of Modernization and Development, London - New York 2005, passim.

${ }^{7}$ Касна модерност, постмодерност, рефлексивна модерност, флуидна модерност синоними су којима се карактерише повезаност модерности са традицијом и њена зависност од западне модерности. Можда је најприхватљивији појам вишеструке модерности, који је у науци афирмисан 2000, захваљујући Ајзенштату и веома утицајном броју часописа Дедалус из те године. Shmuel. N. Eisenstadt, Multiple Modernities, Daedalus, No. 129, 2000, 1-29; Isti, Some Observations on Multiple Modernities u Reflections on Multiple Modernities. European, Chinese and Other Interpretations, (Eds. D. Sachsenmaier, J. Riedel), Leiden Boston - Köln 2002, 27-41; Dominic Sachsenmaier, Multiple Modernities - The Concept and its Potential u Reflections on Multiple Modernities. European, Chinese and Other Interpretations, 42-67; Anđelko Milardović, Druga moderna, Zagreb 2011, 52-5, passim.

${ }^{8}$ Ibrahim Kaya, Social Theory and Later Modernities. The Turkish Experience, Liverpool 2004, 1-28.
} 
модерним, већ поприма нове форме, кроз реинтерпретацију. Није занемарива улога измишљања традиције, с обзиром да транзиционе околности захтевају ревизију, измену или изградњу нових традиционалних образаца. Овај концепт сличан је Андерсоновој идеји о замишљеним заједницама. ${ }^{9}$ Такође, вишеструка модерност не негира вестернизацију, односно утицај Запада или развијених друштава на мање развијена, али модернизацију посматра као аутономан процес. Коначно, вестернизација и модернизација нису идентичне, нити је западна модернизација једина аутентична. Зато касније модернизације нису варијације првобитних, већ идеолошки и институционално нови изазови. Јирген Кока сматра да постоје три начина преузимања модела и његове имплементације у процесу модернизације друштва: наметање, имитација и преговарање, под којим подразумева селективност, реинтерпретацију, модификовану инкорпорацију, односно промене у складу са сопственом традицијом и историјским искуством. ${ }^{10}$ у проучавању интензитета страних утицаја индијски теоретичар национализма Парт Чатерџи сугерише да се они одвијају у материјалном домену, насупрот духовном, иманентно унутрашњем које путем елите креира и властити културни суверенитет. Прасинеџит Дуера истиче управо културу и цивилизацију као централне компоненте аутентичности. ${ }^{11}$

Паралелно са успостављањем теорија модернизације осетио се њихов утицај и у савременој османистици, најпре Успоном Модерне Турске Бернарда Луиса и Развојем секуларизма у турској Нијази Беркеса. ${ }^{12}$ Они су реформским динамизмом побијали, како то Картер Финдли истиче, ревизионистичке стереотипе о „болеснику са Босфора““ и афирмисали реформе XIX века као парадигму османске

\footnotetext{
${ }^{9}$ Еклатантан пример измишљања традиције јесте занемаривање османске историје и реафирмисање хетитских корена турске нације у почетним стадијумима кемализма, како би се турска национална идеја повезала са Анадолијом, који је убрзо напуштен. Међутим, условио је да турски национализам после Првог светског рата и пропасти Османског царства не осети терет пораза, већ се афирмише као победнички, због повратка коренима и изградње националне државе. Erik Hobsbaum, Uvod - Kako se tradicije izmišljaju u (Ur. Erik Hobsbom, Terens Rejndžer), Izmišljanje tradicije, Beograd 2002, 5-25; Can Erimtan, Ottomans Looking West? The Origins of the Tulip Age and its Development in Modern Turkey, London - New York 2008; Benedikt Anderson, Nacija: zamišljena zajednica, Beograd 1998.

${ }^{10}$ Jürgen Kocka, Multiple Modernities and Negotiated Universals u Reflections on Multiple Modernities. European, Chinese and Other Interpretations, 119-28.

11 Појам цивилизације често се користи код теорија модернизације како би се нагласио процес глобализације, при чему се националне државе посматрају радије као цивилизације, како би се избегло пре свега територијално одређење. Насупрот западном становишту о хомогенизацији односно унификовању света по западном моделу, истиче се сукоб цивилизација, идеја коју је у истоименој студији разрадио Самјуел Хантингтон. Поједина радикалнија становишта везана за фундаменталистичке покрете негирају модернизацију и истичу традиционалне вредности као супротност Западу. Раrtha Chatterjee, Nationalist Thought and the Colonial World. A Derivative Discourse, London 1993, Isti, The Politics of the Governed. Reflections on Popular politics in Most of the World, New York, 2004 1-81; Isti, Our Modernity, Rotterdam 1997; Prasenjit Duara, Civilisation and Nations in a Globalizing World u Reflections on Multiple Modernities. European, Chinese and Other Interpretations,79-99; Самјуел Хантингтон, Сукоб цивилизаиија и преобликовање светског поретка, Подгорица - Бања Лука 2000.

${ }^{12}$ Bernard Lewis, The Emergence of Modern Turkey, London - Oxford - New York 1960' Niyazi Berkes, Türkiye'de Çağdaşlaşma, İstanbul 2008. Беркес је првобитно књигу објавио на енглеском 1964. под називом The Development of Secularism in Turkey, да би јој касније придодао други том и тако обједињену публиковао на турском језику поводом педесетогодишњице Турске републике 1973.
} 
европеизације, столетног пута током којег је заостала Османска империја претворена у модерну Турску. Суштинско питање турског идентитета, однос секуларизма и исламизма, како Картер закључује, није могуће одвојити, јер ни данас секуларизам не може искључити религију, али је одговор на питање односа исламизма и модернизма дао почетком XX века теоретичар турског национализма Зија Гокалп утврдивши да је исламска култура део европске цивилизације и да су туркизам и модернизам супротна начела панисламизму и османизму, дакле прогресивна. ${ }^{13} \mathrm{C}$ друге стране Луис и Беркес су афирмацијом XIX века као периода модернизације и изједначавањем појмова модернизације и европеизације означили почетак полувековног наратива који је танзимат посматрао као дисконтинуитет османске историје. Фокусирањем на предмодерно доба основна интенција овог рада је да утврди постоје ли симболички знаци модерности током XVIII века и који се процеси током тог дугог века ${ }^{14}$ могу посматрати као османска аутентичност, односно, језиком Јиргена Коке, шта је наметање, имитација, а шта преговарање.

\section{Османска модернизација - између централизације и децентрализације}

Почивајући на идеологији газе и заснивајући експанзивну економију на експлоатацији, Османско царство „живело је за рат“. Ова широко распрострањена теза у савременој науци само је делимично тачна, или, речима Данијела Гофмана, штетан и погрешан стереотип. ${ }^{15}$ Гофман сматра да је кроз теорију модернизације и периферализацију Османског царства конструисан стереотип о различитости Османлија у односу на Европу, о политичком и социјалном развоју изван оквира европског стандарда. ${ }^{16}$ Поменута полемика упућује на потребу испитивања реалне перцепције Османлија о питању рата и контроверзе у самој историографији. Нема сумње да се Гудвинов закључак не може олако одбацити, али такође не може бити универзалан. У периоду трансформације османског средњег доба, XVII и XVIII веку, идеологија газе није представљала примарну легитимацијску основу, док је са децентрализацијом нарочито израженом у XVIII веку рат постајао непожељан. Од првобитног средства акумулације капитала, употреби ли се марксистичко тумачење, рат је постепено представљао расипање капитала којег реално није било, а самим тим се круг заинтересованих за учешће у њему сводио на малобројне угрожене ајане и локалне скупине неплаћених полувојних формација (levend) у потрази за

\footnotetext{
13 Taha Parla, The Social and Political Thought of Ziya Gökalp 1876-1924, Leiden 1985; Carter Vaughn Findley, Turkey, Islam, Nationalism, and Modernity. A History 1789-2007, Yale 2010.

${ }^{14}$ Не постоји сагласност у савременој османистици око периодизације XVIII века, тако да се узима врло широк распон од 1683. до 1839. као хронолошки оквир века, иако се горња граница често помера на 1699. или 1703, а доња на 1826. односно 1789.

${ }^{15}$ Гофман се супротставља напред изнетој тези Џејсона Гудвина. Видети: Jason Goodwin, Lords of the Horizons. A History of the Ottoman Empire, London 1998, 65; Daniel Goffman, The Ottoman Empire and Early Modern Europe, Cambridge 2002, 1-3.

${ }^{16}$ Инсистира на чињеници да се ране модерне државе нису толико разликовале како се то жели приказати, јер како су у Османском царству управне и војне функције биле повезане, тако је и у институцији шерифа у Енглеској примењен сличан модел. Сулејман Законодавац није водио мање ратова од Карла V и сл. Goffman, Op. cit., 4-20.
} 
запослењем. Како истиче Сураја Фароки, ратови су у XVIII веку постали скупи, што је доводило до повећања пореза, неплаћених испорука, банкрота и рецесије. ${ }^{17}$ Даљим поређењем XVIII века са класичним периодом ${ }^{18}$ истиче се положај тимарника. Како првобитно нису били скупина која је плаћана на терет буџета а представљала је реалну војну снагу, не само да касније та војна формација више није била ефикасна већ је рат угрожавао опстанак производње на тимарским поседима. Системом илтизма и процесом чифтлучења класа тимарника постепено се тржишно оријентисала и убрзо је доминирала тржиштем и контролисала новчане токове, земљишне поседе и систем производње и дистрибуције. Требало би напоменути да су у тим пословима важан сегмент представљали јаничари, односно скупина која више није имала војни већ економски карактер јер су је чинили предузетници који су на тај начин избегавали плаћање пореза и добијали новчану накнаду. Процес еснафизачије јаничара односно јаничаризащије еснафа, како га назива Кафадар, узроковао је повећање номиналног броја активних припадника јаничарских орти са 25.000 на крају владавине Мехмеда III (1595) на 110.000 у време Селима III (1789-1807). Легализација продаје јаничарских места коју је извршио султан Махмуд I 1740. де факто је елиминисала јаничаре као војну формацију, иако је она као таква опстајала до $1826 .{ }^{19}$ После 1740 . држава је морала да обезбеди нову војну формацију како би штитила поредак и границе, са чим директно треба повезати наступајуће реформе.

У контексту европеизације османска историографија дуго је издвајала доба лала као парадигму, протореформски период током којег су Османлије „сусреле Запад“. Новија сазнања пружају донекле ревидирано гледиште о домету европских утицаја. $^{20}$ Анализа сефаретнаме Мехмед-ефендије Јирмисекиза Фатме Гоћек засенила је Дури-ефендијину сефаретнаму, односно историографија је преузимала наратив нагле османске трансформације, у домену политике, друштва и културе. Основна теза је истицала рапидан и свеобухватан продор европских утицаја налажењем поткрепљења оваквом ставу у изградњи палате Саадабад по европском моделу, појави штампе, естетици лала и пацифизму. Већ је Ширин Хамадех у расправи о питању европеизације доказала да се изградња павиљона Саадабад, свега девет месеци по повратку Мехмед-ефендије из Париза, не може сматрати

\footnotetext{
${ }^{17}$ Suraiya Faroqhi, Sultanovi podanici. Kultura i svakodnevica u Osmanskom carstvu, Zagreb 2009, 76-79.

${ }^{18}$ По Иналџику класично доба Османског царства трајало је од 1300. до 1600. Халил Иналџик, Османско иарство. Класично доба 1300-1600, Београд 2003.

${ }^{19}$ Cemal Kafadar, Yeniçeri-Esnaf Relations: Solidarity and Conflict, (Neobjavljena master teza), Montreal 1981; R. Murphey, Yeni Čeri, EI², Vol. 11, 322-331; Ali Çaksu, Janissary Coffee Houses in Late Eighteenth - Century Istanbul u Ottoman Tulips, Ottoman Coffee. Leisure and Lifestyle in the Eighteenth Century, (Ed. Dana Sajdi), London - New York 2007, 117-132; Suraiya Faroqhi, Artisans of Empire. Crafts and Craftspeople Under the Ottomans, London - New York 2009.

${ }^{20}$ О добу лала у историографији видети: Can Erimtan, Ottomans Looking West? The Origins of the Tulip Age and its Development in Modern Turkey, London - New York 2008; Мирослав Павловић, Интерпретација $и$ употреба историје: Доба лала као парадигма архетипског у прошлости, Споменица Историјског архива Срем, бр. 9, Сремска Митровица 2010, 224-240.
} 
европским, већ источним, односно персијским моделом градње. ${ }^{21}$ Париска сефаретнама представља резултат једне протоколарне посете, покушај османског двора да „стави Османлије на менталну мапу француских дворских кругова“ али такође испитује терен за политику пацифизма. Наратив о мирном добу, о преокрету османске политике, присутан у историографији од Рефика и Узунћаршилија ${ }^{22}$ до данас може се, иако то у историографији није тако увек истицано, односити искључиво на европске границе. Зато персијска сефаретнама Дури Ахмед-ефендије указује на важнији спољнополитички изазов, посебно они делови који се односе на војне потенцијале. Да је заинтересованост за експанзију ка истоку била у фокусу владајуће елите сведочи и каснија дипломатска мисија чувеног историчара Мехмеда Рашида, као и подела интересних сфера са Русијом $1724 .{ }^{23}$ У контексту модерности свакако треба истаћи да је Османско царство оријентацијом на дипломатију променило не само начин вођења спољне политике већ перцепцију о месту и улози међу империјама у свом окружењу. Сходно том закључку дипломатске мисије нису утицале на промену политике, колико су представљале манифестацију те промене. Разматрајући питање вестернизације, Илбер Ортајли указује на две значајне прекретнице модерног доба, Тридесетогодишњи верски рат у Европи и неуспешну опсаду Беча код Османлија. Повезујући у веберовском смислу протестантску етику са технолошким променама у Европи, Ортајли са правом истиче османски барок, као симболички знак модерности супротстављајући се изненадном импорту технологије који заступају заговорници теорије модернизације. ${ }^{24}$ Сходно том и сличним гледиштима Османско царство није се ни у једном тренутку одвојило од европског окружења, да би се касније суочило са изненадним напредним друштвом, као заостало периферно друштво. Криза феудалног система, изражена бирократизација, промене у сфери привреде и економије, приватизација поседа како то истиче Ариел Салцман, карактеристика су развоја модерних из степена предмодерних друштава. Питер Берк сликовито описује овај процес као кретање из патримонијалног ка бирократском систему власти. Зато Ортајли, фокусирајући опсаду Беча, указује на (од Карловачког мира) превласт цивилне бирократије као носиоца реформи и модернизације. ${ }^{25}$

Окончање османске експанзије са Карловачким миром довело је до побуне 1703, организоване уједињеним напорима улеме и јаничара-еснафа. Међутим, већ је

\footnotetext{
${ }^{21}$ Shirine Hamadeh, Ottoman Expression of Early Modernity and the "Inevitable“ Question of Westernization, The Journal of Society of Architectural Historians, Vol. 63, No. 1, Mart 2004.

${ }^{22}$ Ahmed Refik, Lale Devri, Istanbul 2005; İsmail Hakkı Uzunçarşili, Osmanlı Tarihi, IV cilt, 1. Bölüm, 2. Başkl, Karlofça anlaşmasından XVIII yüzyılın sonlarına kadar, Ankara 1978, 147-210.

${ }^{23}$ Suraiya Faroqhi, An Ottoman Ambassador in Iran: Dürri Ahmed Efendi and the Collapse of the Safavid Empire in 1720-21 u Another Mirror for Princes. The Public Image of the Ottoman Sultans and its Reception, (Ed. Suraiya Faroqhi), New Jersey 2009, 165-187.

${ }^{24}$ Ilber Ortayli, Tarihimiz ve Biz, Istanbul 2008, 91-106; Ипак, само годину дана раније, у књизи атрактивног назива На путу модернизачије, Ортајли без икаквог теоријског увода вестернизацију повезује са периодом Танзимата и касније. İlber Ortayli, Batılılaşma Yolunda, Istanbul 2007

${ }^{25}$ Ariel Salzmann, An Ancien Régime Revisited: "Privatization"and Political Economy in the Eighteent Century Ottoman Empire, Politics and Society, Vol. 21, Dec. 1993, 393-424; Piter Berk, Istorija i društvena teorija, 36-41.
} 
тада бирократија, било кроз институцију аге харема или реисулкутаба ${ }^{26}$, снажније и трајније утицала на политику османске државе. Док су једни проблеме сагледавали у кризи институција, слабој власти и одрицању од становишта верског конзервативизма, одражавајући ставове поражених, бирократско решење проблема указивало је на, како то Вирџинија Аксан истиче, секуларни наратив. Он се огледао у, пре свега, војним реформама по западном моделу, упознавањем са западним техникама и експертима и коначно културној интеракцији, пре него културном трансферу. ${ }^{27}$ Када је реч о културном домену, доба лала израженим хедонизмом и естетиком лала највише сведочи о прихватању европског профаног стила. Уколико се сагледају дворске интенције, може се уочити покушај имитације европске дворске атмосфере, где је властела окруживала владара. Османско царство, иако у фази урушавања феудалног система, није имало противтежу централној власти која се могла осетити у престоници, већ пре свега на периферији. Такво стање потрајало je све докраја XVIII века, када је децентрализација достигла свој максимум договором најистакнутијих ајана, тзв. Sened-i Ittifak-ом. ${ }^{28}$ Проблем ајана појавио се од тридесетих година XVIII века и повезан је са процесом монетаризације, односно уништавањем феудалног поседа и феудалне ренте. Установљавањем система илтизма преко маликана ${ }^{29} 1695$. држава је добијала преко потребан новац којим је исплаћивала све већи број јаничара, али како је дефицит бивао већи потреба за новцем је прогресивно расла. Осим девалвација монете прошириван је број поседа претвараних у маликане на рачун тимара, што је остављало двојаке последице. С једне стране је класа тимарника прелазила у плаћенике, због чега су се тимарници упуштали у финансијске послове око закупа пореза, што је водило или чифтлучењу или формирању нерегуларних војних формација на које се власт ослањала као на фактор безбедности. Ајани, који су се налазили на челу, као најугледнији локални и све чешће провинцијални представници контролисали су преко мреже потчињених читаве територије номинално признајући централну власт. На тај начин тензије политичке природе у центру су избегнуте. Појава закупаца пореза, као друга директна последица маликанизације, суочила је производно становништво са захтевима који су превазилазили рентабилност. Резултат је њихово напуштање

\footnotetext{
${ }^{26}$ Није познато када је установљена ова институција. Првобитно је реисулкутаб био главни писар у канцеларији нишанџије. Успон реиса почиње после 1654, када је институција великог везира одвојена од палате, да би се почетком XVII века реис нашао на челу три канцеларије Дивана (Бејликчи, Руус и Тахвил), а докраја века и Амеди канцеларије. Први пут се у Сремским Карловцима 1699. појављује као главни Портин преговарач. Докраја века, сам реис је имао сто до сто педесет службеника само у оквирима своје канцеларије. Установљена је и институција главног тумача Дивана (Divan-1 Hümayun Tercüman1). У XIX веку институција реиса прерасла је у министарство спољних послова. İsmail Hakk1 Uzunçarşıll, Osmanlı Devletinin Merkez ve Bahriye Teşkilâtı, Ankara 1988, 242-248.

${ }^{27}$ Virginia Aksan, Islam-Christian Transfers of Military Technology, 1730-1918, European History Online (EGO), Institute of European History (IEG), Jan 14, 2011.

${ }^{28}$ Споразум најмоћнијих ајана које је Мустафа-паша Алемдар (Барјактар) позвао на саветовање у Истанбул 1808, којим је договорена децентрализација и номинално признавање власти султана.

${ }^{29}$ Илтизам је закуп пореза који се заснивао на мукатама, једногодишњим закупима продаваним на јавним аукцијама, који су се касније могли додатно парцелисати и продавати. Маликане подразумевају праксу доживотног закупа.
} 
земље и пролетерски статус који их је водио у плаћеничку војну или било какву другу службу. Реални политички фактор на локалу више нису представљали плаћени државни службеници, већ закупци пореза, који су контролисали земљу и економију. Систем илтизма је био заснован на тржишним принципима, лицитацијама које су успостављале пирамидалну структуру закупа и подзакупа, док је чифтлучење лавирало између пуке експлоатације и производно усмерених фармерских газдинстава под контролом и заштитом моћних ајана. Систем редистрибуције капитала између спахија, јаничара и еснафа више је остављао производним категоријама, а мање држави. Путем увакуфљивања моћни појединци су лични капитал претварали у задужбински номинално, а фактички под контролом зависних лица сопствене интисап мреже, при чему су овакве формације имале улогу кредитора. $^{30}$

Већ од раног XVII века припадност капукулу групацији није имала престиж нити реални политички значај колико повезивање у интисап. ${ }^{31}$ Могућност напредовања непосредно је зависила од протежирања моћног појединца за кога се врши служба. То је уједно била најмоћнија организација која је на интересним основама повезивала центар и периферију. Међусобно надметање више оваквих групација интисапа доводило је до несталности власти, док су поражени остављали наративе о пропасти и декаденцији толико експлоатисане у историографији. ${ }^{32}$ Констатовати да сви они представљају јединствену, конзервативну или традиционалну скупину, услед толико различитих интереса не би било адекватно, али је њихов однос према реформама најчешће био сличан ако не и истоветан, садржан у захтеву за повратком на стара добра времена у најбољем халдуновском маниру. Читав XVIII век обележен је међусобним сукобљавањима која су доводила до насилних преврата и свргавања султана $(1703,1730$. и 1807), односно до смене реформски и антиреформски настројених великих везира. Бирократија Високе порте и Царског дивана, ${ }^{33}$ поменути „секуларни“ приступ полако и сигурно израстала је као антипод, као потпора султанског централизма, и пре свега као групација која је реформе перципирала кроз сарадњу са Европом. Иако је судбина кјатиба била непосредно повезана са интисапом, временом је, до средине XVIII века, дошло до формирања бирократских интисапа који су најпре елиминисали моћ аге харема,

\footnotetext{
${ }^{30}$ Canay Şahin, The Rise and Fall of an Ayan Family in Eighteenth Century Anatolia: The Caniklizades (17371808.), (Neobjavljena doktorska disertacija), Bilkent University, Ankara 2003, 1-38.

31 Узајамна веза патронског и лојалног односа, која је у XVIII веку постала незамењива приликом напредовања у османској служби, нарочито у бирократским структурама Високе порте. Могла је бити и већег обима, захватајући провинцијалне великодостојнике, који су имали своје заштитнике у престоници. 32 Дела османске политичке литературе деле се на три скупине: сијасетнаме, насихатнаме и ислахатнаме. Политички трактати писани као савети султану често се у историографији означавају јединственим појмом насихатнаме. Ислахатнаме су расправе реформистичког садржаја. Видети: Ahmet Yaşar Ocak, Osmanska misao y Historija osmanske države i civilizacije II, (Prir. Ekmeleddin Ihsanoğlu), Sarajevo 2008, 304316; Avigdor Levy, Military Reform and the Problem of Centralization in the Ottoman Empire in the Eighteenth Century, Middle Eastern Studies, Vol. 18, 227-249.

${ }^{33}$ Царски или султански диван (Divan-1 Hümayun) је највише управно тело Османског царства све до танзиматских реформи. Висока порта (Bab-1 Ali) је током овог периода канцеларија великог везира (садразама, везириазама).
} 
затим преузели позицију реисулкутаба и коначно самог великог везира. Први бирократа који је започео реформски процес у Османском царству, претеча европеизације како је то дуго истицано, био је Дамад Ибрахим-паша Невшехирли (1718-1730). Када се има у обзиру утицај који је имао ага харема (кızlar ağası) Хаџи Бешир (1730-1754) ${ }^{34}$ и садразам Коџа Мехмед Рагиб-паша (1757-1763.), стиче се утисак о континуитету бирократске доминације османском политиком. Елиминација сејфија утемељила је и политику пацифизма, обезбедивши реформама најдужи период мира у османској историји који је претходио конфронтацији са Русијом 1768. Конзервативизам улеме, често истицан у контексту побуна, не одражава стање у највишим круговима ове групације, где је дошло до позиционирања по систему породичних веза и повезивања са цивилном бирократијом. Те нове бејефендије постале су мета султанових покушаја контроле, што најбоље илуструју именовања која су султани вршили али и Часови у присуству султана (huzur dersleri), институција која је продубљивала цивилне утицаје и на школски систем илмија. ${ }^{35}$

Измењени друштвени односи уништавали су феудални систем који није имао адекватну замену, због чега је долазило до све веће поларизације центра и периферије и до децентрализације на периферији, упоредо са централизацијом у престоници. Централизација је подразумевала реформе и модернизацију, које су се одвијале у два правца, на теријском нивоу кроз промену наратива насихатнама и првим реформама војних трупа по западном моделу, које би се могле сматрати импортом технологије. Први симболички знак модерности везан је за појаву османске штампарије Ибрахима Мутеферике. Иако је штампана књига остала ограничена на османску елиту и, како истиче Орлин Сабев, представљала краткорочну авантуру, позиционирала је османски интелектуални свет на мапу модерног доба. То је омогућило појаву новина крајем XVIII века ${ }^{36}$, као основног предуслова развоја свести о припадности широј заједници, фундаменталног параметра модерности. Мутеферика је, као интелектуалац и мислилац, Османлијама оставио још трајније завештање. Његово разумевање европске цивилизације, прагматичко схватање модернизације и теорије власти, дијалектички интердисциплинарни приступ и огромна ерудиција чине га претечом османског просветитељства. У својим радовима говори о историјској еволуцији, апострофирајући да је технолошки напредак Запада наступио кроз период конфронтације са Османлијама, односно наглашава екстерни притисак као подстицај променама и насупрот унутрашњег друштвено-политичког развоја. Све то у прилог тези да је модернизација прагматички процес који није праћен признавањем цивилизацијске инфериорности, већ насупрот томе, и који не мора нужно бити праћен дубљим друштвено економским променама. У прилог

\footnotetext{
${ }^{34}$ Jane Hathaway, Beshir Agha. Chief Eunuch of the Ottoman Imperial Harem, Oxford 2005.

${ }^{35}$ Madeline C. Zilfi, Dindarlik Siyaseti: Osmanlı Uleması. Klasik Dönem Sonrası, Ankara 2008; Ista, A Medrese for the Palace: Ottoman Dynastic Legitimation in the Eighteenth Century, Journal of the American Oriental Society, Vol. 113, No. 2, 184-99; Ebül'ula Mardin, Huzur Dersleri 1, 2, 3, İstanbul 1951-66.

${ }^{36}$ Реч је о новинама на другим језицима, прве званичне османске новине Takvim-i Vekayi (Календар догађаја) су почеле да излазе 1831. Три године раније Мехмед-паша је у Египту покренуо новине на османском и арапском Vekayi-i Mısriyye.
} 
реформама иде и теза да је јака војна организација основа сваког поретка, при чему изоставља признање да под тим подразумева апсолутистички поредак. ${ }^{37}$

Научном афирмацијом тезе о конструкцији насихатнама у корист одређене социјалне групације Рифата ел Хаџа, а што је доказао и Габријел Питерберг када је реч о XVII веку, ${ }^{38}$ теоријско утемељење владајућег поретка, политике пацифизма и модернизације присутно код Мутеферике показује у пуном светлу снагу бирократије, али и својеврсни континуитет са Наимом и Рашидом. Како се код њих може уочити критика повећане социјалне покретљивости, одсликавање кризе система који угрожава нова бирократија, тако се од средине века реформе и пацифизам позиционирају као доминантне теме политичке литературе. До реформи Селима III више није било дилеме у интелектуалним круговима о реформама и модернизацији по западном узору, већ само о модалитетима. Побуном против султана 1807. нови поредак који је у реакцији незадовољних рушен није имао алтернативу, што је постало јасно и његовим противницима, на шта их је упозоравао стари Коџа Сегбанбаши. ${ }^{39}$ Упоредо је долазило до манифестне промене у месту и улози султана у османском свету, инсистирањем на систему праведности и на заштитничком карактеру владара подређивањем идеологије газе. Међутим, неуспех реформи све до Махмуда II сведочи у прилог тези о крхкости владајуће елите, која није успевала да обезбеди адекватну војну потпору, али и о диференцијацији елите или појави владајућих елита које су у честим борбама за власт занемаривале општи интерес.

\section{Османлије и Европа - перцепције и сарадња}

Један од основних параметара модерности према Гиденсу је разумевање простора од стране појединца. Осећај припадности широј заједници од локалне, имагинарној, и дефинисан однос према алтеритету, предуслов су организовања ширих друштвених заједница, посебно нације. Примењена теорија модернизације ограничена је на интеркултурално разумевање Османлија са Европљанима, које се сагледава у контексту „сусрета са Европом“. Тај изненадни судар, како се жели приказати, поткрепљује тезу о периферном друштву које покушава да надомести свој технички, материјални и у крајњем смислу цивилизацијски заостатак. Без оспоравања тезе о технолошкој напредности Запада, потребно је преиспитати појам

\footnotetext{
${ }^{37}$ Orlin Sabev, İbrahim Muteferrika ya da İlk Osmanlı Serüveni (1726-1746.), İstanbul 2006; Vefa Erginbaş, Forerunner of the Ottoman Enlightment: Ibrahim Müteferrika and His Intellectual Landscape, (Neobjavljena master teza), Sabanc1 University 2005; Ahmed Refik, İbrahim Müteferrika y Alimler ve Sanatkarlar, İstanbul 1924, 329-358, J. H. Mordmann, Ibrahim Müteferrika y EI¹, Vol. 8, 439.

${ }^{38}$ Rifa'at 'Ali Abou-El-Haj, Formation of The Modern State. The Ottoman Empire, Sixteenth to Eighteent Centuries, New York 2005; Isti, The Ottoman Vezir and Paşa Households 1683-1703: A Preliminary Report, Journal of American Oriental Society, Vol. 94, No. 4, 1974, 438-47; Gabriel Piterberg, An Ottoman Tragedy. History and Historiography at Play, Berkeley - Los Angeles - London 2003.

${ }^{39}$ Ergin Çă̆man, III Selim'e Sunulan İslahat Lâyihaları, İstanbul 2010; Virginia Aksan, Ottoman Political Writing 1768-1808, International Journal of Middle East Studies, Vol. 25, No. 1, 1993.
} 
„сусрета“. У том смислу, субјект посматрања - Османлије, биће ограничен на османску владајућу класу без обзира на етничко порекло. ${ }^{40}$

Две утицајне студије из средине осамдесетих година XX века својим прозаичним насловима највише су утицале на креирање наратива о сусрету Османлија са Европом. Док Фатма Гоћек сведочи својим архивским радом у прилог тези, код Бернарда Луиса наслов не кореспондира са самим текстом у овом контексту. У првом случају реч је о поменутој дипломатској мисији Мехмедефендије Челеби Јирмисекиза у Париз 1720/1. која је представљена као синоним за интердржавне контакте током целог века. Луис, напротив тезом о муслиманском открићу, заправо сведочи о процесу средњег трајања, о контактима и разумевањима међу цивилизацијама. ${ }^{41}$ Број оних који су посећивали Османско царство са Запада није се рапидно повећао у XVIII веку, нити је то време изненадних одлазака Османлија у европске земље, како се то може закључити код Гоћекове. Трговина у којој су учествовале Османлије први је прозор према Европи, и он није производ XVIII већ претходног века, када је у самој Венецији основана османска трговинска постројбина, Fondaco dei Turchi. ${ }^{42} \mathrm{C}$ друге стране, продор европских трговаца, нарочито Француза, допринео је процесу интеграције османске економије у европски привредни систем, док је сарадња на локалу елиминисала стереотипе о другима и градове попут Измира, Истанбула и Алепа претварала у праве медитеранске мултиетничке средине. ${ }^{43}$ Оно што је разликовало Османлије и Европљане од предака јесте перцепција једних о другима. Док у ранијим периодима у Европи постоји страх од Турака, нарочито код народа који су antemurale christianitatis, како престаје војна опасност, почиње извесна опсесија Оријентом, од Мери Монтегју ${ }^{44}$ до Нервала и Шатобријана, опсесија која код појединаца прелази у презир према „варварству“ (Волтер), односно од мистериозног Оријента до оријентализма како то карактерише Едвард Саид. ${ }^{45}$ Међутим, када је реч о открићу, несумњиво је то век када су две цивилизације - исламска и хришћанска, европска -

\footnotetext{
${ }^{40}$ Suraiya Faroqhi, Sultanovi podanici, 64, 116-117.

${ }^{41}$ Fatma Müge Göçek, East Encounters West. France and the Ottoman Empire in the Eighteenth Century, Oxford 1987 ; Bernard Luis, Muslimansko otkriće Evrope, Beograd $2004\left(1985^{1}\right)$.

42 Juergen Schulz, Early Plans of the Fondaco dei Turchi, Memoirs of the American Academy in Rome, 1997, No 42, 149-159; Yücel Özkaya, 18. Yüzyılda Osmanlı Toplumu, Istanbul 2008, 125-144.

${ }^{43}$ Daniel Goffman, Izmir and the Levantine World 1550-1650, Washington 1990; Edhem Eldem, Daniel Goffman, Bruce Masters, The Ottoman City between East and West. Aleppo, Izmir and Istanbul, Cambridge 1999.

${ }^{44}$ The latters and Works of Lady Mary Wortley Montagu vol. 1-3, (Ed. Lord Wharncliffe), London 1837.

45 Западно поимање Оријента Саид је довео до конструкције, јер ако би се његова теза применила на Османлије, проистиче да је „све веће европско знање о њима од средине XVIII века, ојачано колонијалним упознавањем и генерисано из моћи“ креирало њихов идентитет. Иако би се могао тумачити као први директан покушај супротстављања теорији модернизације, Саидов приступ негира постојање идентитета независно од Запада. Како је прво издање настало 1978, Луисово Муслиманско откриће Европе могло би се сматрати добрим панданом Саидовим тезама. Неки савремени аутори (попут Марије Тодорове) примењују сличан приступ посматрању европског Истока или европске периферије. Сам Саид, прилично оспораван, проширио је своју теорију истицањем „културног отпора“ империјализму, односно културе као извора идентитета. Edvard Said, Orijentalizam, Beograd 2008, 42-57; Edward W. Said, Culture and Imperialism, New York 1993.
} 
спознавале једна другу, проналазиле сличности, разбијале стереотипе архинепријатеља, када је страх елиминисала научна знатижеља. У том контексту може се говорити о османској ренесанси. Недостатак интересовања и интелектуалне радозналости муслимана за ванисламски свет окончан је потребом укључивања у европске дипломатске односе, нарочито са појавом хабзбуршке и руске претње на границама. С друге стране, европско просветитељство до Наполеонове инвазије на Египат 1798. је већ припремило терен за научно проучавање Оријента, односно, како истиче Бернард Луис, само средњовековне историографске продукције која је вероватно богатија од историографије свих европских држава. ${ }^{46}$ Развој дипломатских односа са европским државама допринео је промени перцепција о непријатељу, односно легитимисање преко алтеритета, где је сопствена цивилизација супериорнија, под теретом војних пораза запало је у кризу. Самодовољност се претворила у страх од аутаркичности. Османски интелектуалци све чешће су употребљавали термин декаденција. ${ }^{47} \mathrm{C}$ друге стране, слика Турака који више нису представљали симбол страха у Европи се од неверника докраја XVIII века претварала у варварина, од религијске ка цивилизацијској дисквалификацији. ${ }^{48}$

На потребу редефинисања односа према европским државама указала је странка која се противила рату 1714-1718, на чијем се челу налазио будући велики везир Дамад Ибрахим-паша. Сарадња између њега и Маркиза де Бонака, француског амбасадора (1716-1724), допринела је знатно нијансиранијој политици Француске према Османском царству. Дипломатски наступ Ибрахим-паше означио је почетак доба бирократије у османској држави, која је разумела чињеницу да је француски амбасадор био кључна личност у потрази за савезником османске политике према Европи. ${ }^{49}$ Упоредо је дошло до осетног пада француске левантске трговине, што би могао бити један од разлога приближавања са француске стране. Концентрисана највећим делом између Марсеља и Измира, трговина постаје незаобилазан политички чинилац, како због њене експанзије тако и због суверене доминације коју су Французи имали у овом послу. Током двадесетих и тридесетих година Де Вилнев и Морепас као француски амбасадори успели су да утврде положај марсељских трговаца у Османском царству, што је после обнове капитулација 1740. довело до

\footnotetext{
${ }^{46}$ Bernard Luis, Muslimansko otkriće Evrope, 211.

${ }^{47}$ Иако се теорија декаденције дуго под утицајем наративних извора задржала и у историографији, данас je дефинитивно поражена. Термином децентрализације који је доминирао од средине деведесетих година XX века није се постигло много више осим супротстављања сагледавању XVIII века као мрачног периода османске историје. Континуирана трансформација данас је најприхватљивији појам с обзиром да је током периода који је обележила политичка фрагментација аукцијама пореских закупа престоничка елита креирала услове којима је периферија остала зависна од центра. Donald Quataert, Ottoman History Writing and Changing Attitudes Towards the Notion of "Decline”, History Compas,Vol. 1, August 2003, 38-48; Şerif Mardin, Center - Periphery Relations: A Key to Turkish Politics, Daedalus, Vol. 101, No. 1, 1973, 169-190.

${ }^{48}$ Imaginarni Turčin, (Ur. Božidar Jezernik), Beograd 2010; Iver B. Neumann, Uses of the Other. „,The East“ in European Identity Formation, Minneapolis 1999, 39-64.

${ }^{49}$ О односу Ибрахим-паше и Маркиза де Бонака, као и о приоритету који је, као посебан вид указивања почасти, добио амбасадор приликом сунећења принчева видети: Suraiya Faroqhi, Negotiating a Festivity in the Eighteenth Century: Ibrahim Paşa and the Marquis be Bonnac, 1720 u Another Mirror for Princes, 149-163.
} 
експанзије француске трговине. Док су се енглески и холандски трговци повлачили из левантске трговине, француски утицај је растао, због чега је већ почетком века Француска постала најзначајнији трговачки партнер Османског царства, па је од средине века у њеним рукама било концентрисано две трећине европске трговине са Левантом. ${ }^{50}$ У другој половини века расте интересовање за техничке производе, као и за покушај њихове производње у Османском царству. То није довело до веће мануфактурне производње или зачетка индустријализације, иако је било покушаја. Главни разлог је немогућност постизања одговарајућег квалитета. Утицаји француске трговине на пољу европеизације ограничени су на формирање слоја комерцијалне буржоазије међу немуслиманским народима, која је у периоду наступајућих националних револуција била значајан фактор. Међу њима се истиче слој Османлија хришћанског порекла школованих на европским универзитетима, или оних попут Димитрија Кантемира који су отварали једну другу перспективу интеракција са Европом. ${ }^{51}$

Разумевањем културног наратива као интеракције уместо трансфера објашњава се већ помињаним перцепцијама Оријента међу Европљанима. Ако се занемари „конструкција Оријента”, како то истиче Саид, и ако се присуство европског код Османлија назове модернизацијом, поставља се питање дефиниције присуства оријенталног у Моцартовом Турском маршу, или османске теме у Волтеровом Кандиду односно Русоовом Емилу. Насупрот томе потребно је разграничити спорадичне представе о далеком, непознатом и другачијем које су се јављале у литератури од перцепција под чијим је утицајима долазило до коренитих промена у друштву. У ову категорију могу се сврстати и Париска сефаретнама и Волтер, Русо и Моцарт. Међутим, развој милитарне технологије и установљење војних корпуса по европском моделу не може представљати интеракцију већ искључиво трансфер. Војне реформе су вршене у два корака, најпре прихватањем странаца у османску службу за војне саветнике који су нужно морали примити ислам (mühtadi) и касније њиховим либералнијим третманом, када верско опредељење није било довођено у питање. У првом кораку формирани су војни корпуси, док је у другом дошло до реформи војно-образовног система. Иако је долазило до укидања корпуса и каснијих обнова, јасан је тренд установљења модерних војно-поморских формација на које се ослањао бирократски централизам. Број странаца константно је растао, док је њихова улога проширивана. Када су ушли у учионице и организовали предавања на европским језицима и литератури, није се

\footnotetext{
${ }^{50}$ Иако је обим спољнотрговинске размене током века варирао, ипак је ишао узлазном путањом, а после криза и ратова следио је брзи опоравак. Увоз у Марсељ из Османског царства је са десетак милиона ливара почетком века достигао 60 милиона крајем века, док је француски дефицит износио до 15 милиона ливара, што је покривано обалским транспортом који су вршили француски бродови. Видети: Edhem Eldem, French Trade in Istanbul in Eighteenth Century, Brill 1999, 13-33.

${ }^{51}$ Кантемир је као део османске владајуће елите школован у Истанбулу, да би касније пребегао у Русију. Био је писац и архитекта, а занимао се и за музику. Његова Историја Османског царства оставила је дубок утицај у савременој Европи, док је током боравка у Истанбулу представљао посредника, омогућивши образованим Османлијама (међу којима је био и велики везир Мехмед-паша Рами) да упознају европску културу. S. Faroqhi, Sultanovi podanici, 112-117.
} 
више могла спречити научна знатижења младих Османлија које су откривале ренесансу, просветитељство, а убрзо и демократске тековине Француске револуције. Први предлог о формирању корпуса страних војних инжињера поднео је Дамад Ибрахим-паши конт Де Рошфорт ${ }^{52}$, француски хугенот, али је услед преврата патрона Халила 1730, тек конт Клод Александар де Боневал (Humbarac1 Ahmed Paşa) добио султанов пристанак. Осим артиљеријске јединице основана је 1734. инжињеријска школа, која је под притиском убрзо затворена. И треће велико име османске модернизације долази из Француске, барон Де Тот је 1776. основао Царску поморско-инжињеријску школу. Следећи и најобимнији реформски циклус покренуо је Селим III означивши прекретницу у школству отварањем војних школа у којима су се изучавала достигнућа европске науке по европском школском систему. ${ }^{53}$ Цикличност реформи, односно стални прекиди, укидања и поновна успостављања нових војних јединица везани су за превирања међу османском елитом у центру и поларизацију где је део елите тражио подршку међу онима којима је нови поредак укидао привилегије.

Примењена теорија модернизације у савременој османистици утицала је на афирмацију реформи посматраних у контексту вестернизације односно модернизације која је периферно и предмодерно друштво требало да доведе до степена модерности и по унутрашњим особинама унификује и инкорпорира у европски систем. Ако се занемари чињеница да је ова периферија опстала као таква, не достигавши своју модерност, теорија модернизације креирала је и својеврстан наратив о модернизацији од танзимата, пропуштајући да контекстуализује предтанзиматске реформе. Модернизација се посматра искључиво као вестернизација (у ранијим раздобљима европеизација), због чега остаје нејасна граница између културне интеракције и трансфера. У том контексту није одређена граница између форсиране и аутономне модернизације, односно између наметнутог услед спољних или унутрашњих притисака и аутохтоног, иманентног историјском развоју самог друштва. Та граница се у крајњем смислу идентификује у домену материјалног и духовног. Теоретичари који указују да се трансфер врши искључиво у материјалној сфери док је духовна одраз аутентичности, попут Чатерџија или чак Саида у новијим радовима, не само да заступају идеју вишеструке модерности, већ указују на потребу сагледавања духовног при анализи материјалног.

Појам модерности се, независно од односа национализма и модернизма(!), повезује са националном државом, због чега се не може говорити о модерним државама пре Француске револуције. Међутим, прелаз из предмодерне фазе у модерну карактеришу истоветни или слични процеси обележени, како то истиче Гиденс, симболичким знацима. Разматрање реформи и промена у домену културе, економије, политике, интелектуалне мисли, свакодневног живота током османског XVIII века требало би да укаже на симболичке знаке модерности, разграничи

\footnotetext{
52 Претпоставља се један од четири мускетара Александра Диме.

53 Детаљан списак странаца у османској служби погледати у: Mehmet Alaaddin Yalçınkaya, Osmanlı Devleti'nin Modernleşme Sürecinde Avrupalılar'ın Istihdam Edilmesi (1774-1807) u Osmanlılar ve Avrupa. Seyahat, Karşılaşma ve Etkileşim, (Ed. Seyfi Kenan), İstanbul 2010, 421-448
} 
аутохтоно од трансфера и коначно укаже на потребу сагледавања континуитета османске историје, где се реформе не појављују изненада, не раскидају са прошлошћу већ репрезентују централистичке тежње османске бирократије. Посебну пажњу потребно је усмерити на кризу феудализма као јасном симболичком знаку модерности, али и на, сходно Берку, прелазак из патримонијалног на бирократски систем власти. Управо стога што је криза феудализма довела до децентрализације, до губитка ефикасне контроле централне администрације у провинцијама, где се почињу развијати капиталистички односи, као пример културне интеракције, односно трговине са европским државама. Оставши без одговарајуће војне силе, ограничених материјалних могућности, централна власт је прибегла политици пацифизма, дипломатији и коначно модернизацији. Османски интелектуалци који су учили на европском искуству још тада су разликовали духовно богатство и „исламску цивилизацијску супериорност“ од техничке надмоћности Запада. Модернизација је представљала трансфер технике, испрва војне, али колико је развој војне силе служио одбрани Царства, толико је јачао бирократски централизам. Током XVIII века, закључно са реформама Селима III, постављене су основе танзиматских реформи, које су следиле колико трансферисан западни модел толико и сопствено историјско искуство.

Извори и литература:

Abou-El-Haj Rifa'at, 'Ali, Formation of The Modern State. The Ottoman Empire, Sixteenth to Eighteent Centuries, New York 2005

Abou-El-Haj, Rifa'at, 'Ali, The Ottoman Vezir and Paşa Households 1683-1703: A Preliminary Report, Journal of American Oriental Society, Vol. 94, No. 4, 1974

Aksan, Virginia, Islam-Christian Transfers of Military Technology, 1730-1918, European History Online (EGO), Institute of European History (IEG), Jan 14, 2011

Aksan, Virginia, Ottoman Political Writing 1768-1808, International Journal of Middle East Studies, Vol. 25, No. 1, 1993

Anderson, Benedikt, Nacija: zamišljena zajednica, Beograd 1998

Bearman, Bianquis, Bosworth, Donzel, Henrichs, eds, The Encyclopaedia of Islam. New Edition, Vol. XI, Leiden 2002

Berk, Piter, Istorija i društvena teorija, Beograd 2002

Berkes, Niyazi, Türkiye'de Çă̆daşlaşma, İstanbul 2008

Chatterjee, Partha, Nationalist Thought and the Colonial World. A Derivative Discourse, London 1993

Chatterjee, Partha, The Politics of the Governed. Reflections on Popular politics in Most of the World, New York, 2004 1-81; Isti, Our Modernity, Rotterdam 1997

Çağman, Ergin, III Selim'e Sunulan İslahat Lâyihaları, İstanbul 2010

Çaksu, Ali, Janissary Coffee Houses in Late Eighteenth-Century Istanbul u Ottoman Tulips, Ottoman Coffee. Leisure and Lifestyle in the Eighteenth Century, (Ed. Dana Sajdi), London - New York 2007 
Duara, Prasenjit, Civilisation and Nations in a Globalizing World u Reflections on Multiple Modernities. European, Chinese and Other Interpretations (Eds. D. Sachsenmaier, J. Riedel), Leiden - Boston - Köln 2002

Eisenstadt, Shmuel. N, Multiple Modernities, Daedalus, No. 129, 2000

Eisenstadt, Shmuel. N, Some Observations on Multiple Modernities u Reflections on Multiple Modernities. European, Chinese and Other Interpretations, (Eds. D. Sachsenmaier, J. Riedel), Leiden - Boston - Köln 2002

Eldem, Edhem, Goffman Daniel, Masters Bruce, The Ottoman City between East and West. Aleppo, Izmir and Istanbul, Cambridge 1999

Eldem, Edhem, French Trade in Istanbul in Eighteenth Century, Brill 1999

Erginbaş, Vefa, Forerunner of the Ottoman Enlightment: Ibrahim Müteferrika and His Intellectual Landscape, (Neobjavljena master teza), Sabanc1 University 2005

Erimtan, Can, Ottomans Looking West? The Origins of the Tulip Age and its Development in Modern Turkey, London - New York 2008

Faroqhi, Suraiya, Sultanovi podanici. Kultura i svakodnevica u Osmanskom carstvu, Zagreb 2009

Faroqhi, Suraiya, Artisans of Empire. Crafts and Craftspeople Under the Ottomans, London - New York 2009

Faroqhi, Suraiya, An Ottoman Ambassador in Iran: Dürri Ahmed Efendi and the Collapse of the Safavid Empire in 1720-21 u Another Mirror for Princes. The Public Image of the Ottoman Sultans and its Reception, (Ed. Suraiya Faroqhi), New Jersey 2009

Findley, Carter Vaughn, Turkey, Islam, Nationalism, and Modernity. A History 1789-2007, Yale 2010

Gidens, Entoni, Posledice modernosti, Beograd 1998

Goffman, Daniel, The Ottoman Empire and Early Modern Europe, Cambridge 2002

Goffman, Daniel, Izmir and the Levantine World 1550-1650, Washington 1990

Goodwin, Jason, Lords of the Horizons. A History of the Ottoman Empire, London 1998

Göçek, Fatma Müge, East Encounters West. France and the Ottoman Empire in the Eighteenth Century, Oxford 1987

Hamadeh, Shirine, Ottoman Expression of Early Modernity and the "Inevitable" Question of Westernization, The Journal of Society of Architectural Historians, Vol. 63, No. 1, Mart 2004

Хантингтон, Самјуел, Сукоб цивилизација и преобликовање светског поретка, Подгорица Бања Лука 2000

Harrison, David, The Sociology of Modernization and Development, London - New York 2005

Hathaway, Jane, Beshir Agha. Chief Eunuch of the Ottoman Imperial Harem, Oxford 2005

Hobsbaum, Erik, Uvod - Kako se tradicije izmišljaju u (Ur. Erik Hobsbom, Terens Rejndžer), Izmišljanje tradicije, Beograd 2002

Иналџик, Халил, Османско иарство. Класично доба 1300-1600, Београд 2003

Jezernik, Božidar Ur, Imaginarni Turčin, Beograd 2010

Kafadar, Cemal, Yeniçeri-Esnaf Relations: Solidarity and Conflict, (Neobjavljena master teza), Montreal 1981

Kaya, Ibrahim, Social Theory and Later Modernities. The Turkish Experience, Liverpool 2004

Kocka, Jürgen, Multiple Modernities and Negotiated Universals u Reflections on Multiple Modernities. European, Chinese and Other Interpretations (Eds. D. Sachsenmaier, J. Riedel), Leiden - Boston - Köln 2002

Levy, Avigdor, Military Reform and the Problem of Centralization in the Ottoman Empire in the Eighteenth Century, Middle Eastern Studies, Vol. 18

Lewis, Bernard, The Emergence of Modern Turkey, London, Oxford, New York 1960 
Luis, Bernard, Muslimansko otkriće Evrope, Beograd 2004 (1985 $\left.{ }^{1}\right)$

Mardin, Ebül'ula, Huzur Dersleri 1,2,3, İstanbul 1951-66

Mardin, Şerif, Center -Periphery Relations: A Key to Turkish Politics, Daedalus, Vol. 101, No. 1, 1973

Марковић, Предраг, Теорија модернизаиије и њена критичка примена на међуратну Југославију и друге источноевропске земље, Годишњак за друштвену историју, бр.1, Београд 1994

Марковић, Предраг, Конщепт модернизације и/или вестернизаџије у новијој српској историји: одбацити или преиспитати?, Култура полиса, број 1, Нови Сад 2004

Milardović, Anđelko, Druga moderna, Zagreb 2011

Neumann, Iver B, Uses of the Other. „,The East“ in European Identity Formation, Minneapolis 1999

Ocak, Ahmet Yaşar, Osmanska misao y Historija osmanske države i civilizacije II, (Prir. Ekmeleddin Ihsanoğlu), Sarajevo 2008

Ortayli, Ilber, Tarihimiz ve Biz, Istanbul 2008

Ortayli, İlber, Batılılaşma Yolunda, Istanbul 2007

Özkaya, Yücel, 18. Yüzyılda Osmanlı Toplumu, Istanbul 2008

Parla, Taha, The Social and Political Thought of Ziya Gökalp 1876-1924, Leiden 1985

Павловић, Мирослав, Интерпретација и употреба историје: Доба лала као парадигма архетипског у прошлости, Споменица Историјског архива Срем, бр. 9, Сремска Митровица 2010

Перовић, Латинка, Између анархије и аутократије. Српско друштво на прелазима векова (XIX-XXI), Београд 2006

Piterberg, Gabriel, An Ottoman Tragedy. History and Historiography at Play, Berkeley - Los Angeles - London 2003

Quataert, Donald, Ottoman History Writing and Changing Attitudes Towards the Notion of "Decline”, History Compas, Vol. 1, August 2003

Refik, Ahmed, Lale Devri, Istanbul 2005

Refik, Ahmed, İbrahim Müteferrika y Alimler ve Sanatkarlar, İstanbul 1924

Sabev, Orlin, İbrahim Muteferrika ya da İlk Osmanlı Serüveni (1726-1746.), İstanbul 2006

Sachsenmaier, Dominic, Multiple Modernities-The Concept and its Potential u Reflections on Multiple Modernities. European, Chinese and Other Interpretations (Eds. D. Sachsenmaier, J. Riedel), Leiden - Boston - Köln 2002

Said, Edvard, Orijentalizam, Beograd 2008

Said, Edward W, Culture and Imperialism, New York 1993

Salzmann, Ariel, An Ancien Régime Revisited: “Privatization"and Political Economy in the Eighteent-Century Ottoman Empire, Politics and Society, Vol. 21, Dec. 1993

Schulz, Juergen, Early Plans of the Fondaco dei Turchi, Memoirs of the American Academy in Rome, 1997, No 42

Smith, Antony D, Nationalism and Modernism. A Critical Survey of Recent Theories of Nations and Nationalism, London - New York 1998

Şahin, Canay, The Rise and Fall of an Ayan Family in Eighteenth Century Anatolia: The Caniklizades (1737-1808.), (Neobjavljena doktorska disertacija), Bilkent University, Ankara 2003

Teokarević Jovan, Modernizacija i društveni razvoj, Beograd 1990

Uzunçarşili İsmail Hakkı, Osmanlı Tarihi, IV cilt, 1. Bölüm, 2. Başkı, Karlof̧̧a anlaşmasından XVIII yüzyılın sonlarına kadar, Ankara 1978

Uzunçarşıllı, İsmail Hakkı, Osmanlı Devletinin Merkez ve Bahriye Teşkilâtı, Ankara 1988

Wharncliffe, Lord Ed, The latters and Works of Lady Mary Wortley Montagu vol. 1-3, London 1837 
Yalçınkaya, Mehmet Alaaddin, Osmanlı Devleti'nin Modernleşme Sürecinde Avrupalılar'in İstihdam Edilmesi (1774-1807) u Osmanlılar ve Avrupa. Seyahat, Karşılaşma ve Etkileşim, (Ed. Seyfi Kenan), İstanbul 2010

Zilfi, Madeline C, Dindarlik Siyaseti: Osmanlı Uleması. Klasik Dönem Sonrası, Ankara 2008

Zilfi, Madeline C, A Medrese for the Palace: Ottoman Dynastic Legitimation in the Eighteenth Century, Journal of the American Oriental Society, Vol. 113, No. 2 


\title{
FORCED OR AUTONOMOUS MODERNIZATION? OTTOMAN REFORMS IN THE EIGHTEENTH CENTURY IN THE CONTEXT OF EUROPEAN INFLUENCES
}

\begin{abstract}
Summary
The paper examines a development of modernization theories, and their influence in the contemporary Ottoman study, imprecise terminology of the concepts 'modernization' and 'Westernization (Europeanization)', with special emphasis on the contemporary thesis of multiple modernity. The relationship between cultural transfer and interaction, material and spiritual, was specially observed in order to determine the relationship between the impact of modern societies on the traditional societies, through the model of imposed modernization and autonomous development, immanent to the historical experience of the society which was developed from a pre-modern to a modern society. Perceptions of alteration were analyzed, and there was an attempt to identify the symbolic signs of modernity, as Anthony Giddens pointed out, i.e. the features which were not typical for traditional societies, in order to specify the nature of the Ottoman modernity.
\end{abstract}

Keywords: Ottoman Empire, the eighteenth century, modernization, multiple modernity, Westernization, reform, decentralization, centralization, cultural interaction, cultural transfer 